\title{
Carbon Stocks of Coastal Wetland Ecosystems on Hainan Island, China
}

\author{
Tianlun Gao*, Dongjing Ding, Wei Guan, Baowen Liao \\ Research Institute of Tropical Forestry, Chinese Academy of Forestry
}

Received: 28 July 2017

Accepted: 19 August 2017

\begin{abstract}
Coastal wetland ecosystems have a great capacity to store carbon $(\mathrm{C})$, and the condition has a significant influence on carbon emissions and segregation. This study aims to estimate carbon stocks in both vegetation and soil of coastal wetland ecosystems, and to compare the $\mathrm{C}$ stocks of different ecosystems and soil layers. This study classified coastal wetland ecosystems into six types, and C stocks were quantified through the measurement of vegetation biomass and soil $\mathrm{C}$. The $\mathrm{C}$ stocks of estuaries, muddy beaches, coastal saltwater lakes, mangroves, deltas, and seagrass beds were 210.73, 243.00, 167.41, 426.57, 185.88, and 297.85 $\mathrm{MgC} \mathrm{ha}^{-1}$, respectively. Mangroves were found to be the most carbon-rich ecosystem. The total organic C content (TOC) of soil decreased with soil depth and was the highest in the top 0-20 cm layer. The total $\mathrm{C}$ storage of coastal wetland ecosystems in Hainan Island was $56.51 \times 10^{5}$ $\mathrm{Mg}$ of $\mathrm{C}$. These estimates show that there is an urgent requirement to protect coastal wetland ecosystems.
\end{abstract}

Keywords: coastal wetland ecosystems, carbon stocks, ecosystem carbon stocks, soil C stocks, Hainan Island

\section{Introduction}

As increasing $\mathrm{CO}_{2}$ concentration leads to climate warming, it influences various sides of ecosystems. Some climate change influences on ecosystems have been studied. For instance, the radiation-based models were selected as the best model to estimate potential evapotranspiration with respect to climate change [1]. Due to the surface water supply index, different hydrological conditions from extremely wet to extreme drought were investigated [2]. Furthermore, a new approach for environmental crises with climate change and its solutions by computer modeling were found [3]. Meanwhile, methods of increasing carbon (C) sequestration of

*e-mail: frankgao@yahoo.com ecosystems raise a global concern. C sequestered by coastal ecosystems is called 'blue carbon' [4], which has been proven to occupy tremendous C stocks [5]. Therefore, it is vital to understand ecosystem functions and their roles, and to assess the millennium ecosystem. A report produced by the FAO and IOC-UNESCO noted that coastal ecosystems such as mangroves, salt marshes, and seagrass beds were responsible for capturing $70 \%$ of $\mathrm{C}$ permanently stored in the marine environment. However, these ecosystems are disappearing faster than those on land [4]. The destruction of coastal ecosystems leads to a considerable reduction in the potential for sequestration of C. Land use change presents the greatest threat to coastal ecosystems [6]. In particular, 50\% of coastal wetlands and even $76.34 \%$ size of mangroves have disappeared since the 1950s on Hainan Island [7]. Expansion of construction land and aquaculture development are major problems 
for the protection of coastal ecosystems in China [8]. In response, cooperative projects have been launched, such as the Reducing Emissions from Deforestation and Forest Degradation Program (REDD+) [9], which is based on research into ecosystem $\mathrm{C}$ stocks and emission factors associated with land use change [10]. Accordingly, assessing the effect of rapid land use change is urgent by calculating $\mathrm{C}$ stocks of coastal ecosystems.

Although wetlands cover only $2-6 \%$ of the earth's surface [4], soil organic carbon (SOC) stocks of wetlands hold approximately one-third of global SOC stocks [11]. Coastal wetlands possess special hydrology, vegetation, and soil characteristics [12] that play an important role in carbon stocks [13]. Carbon stocks of mangrove ecosystems in the Indo-Pacific region [14] and Micronesia [15] were calculated. Global blue carbon emissions from the degradation of coastal ecosystems were estimated [16]. The first research of C stocks of coastal wetlands in the American tropics has been reported [17]. However, the amount of $\mathrm{C}$ storage has not been calculated for coastal wetland ecosystems of Hainan Island. Thus, calculating $\mathrm{C}$ stocks of coastal wetlands on Hainan is necessary.

According to remote sensing (RS) technology and field research, nine types of natural coastal wetland ecosystems are located on Hainan, namely shallow waters, sandy coasts, rocky coasts, seagrass beds, mangroves, estuarine waters, muddy beaches, deltas, and coastal saltwater lakes [18]. Shallow waters, sandy coasts, and rocky coasts wholly consist of gravel, preventing vegetation growth. The gravel is composed of calcium carbonate. Thus, we can ignore their C-stock potential. We estimated $\mathrm{C}$ stocks in the vegetation biomass and soil of six types of coastal wetlands including seagrass beds, mangroves, estuarine waters, muddy beaches, deltas, and coastal saltwater lakes.

There are three sources of uncertainty that they are more considerable in the previous studies, including limiting the estimation of single-type coastal wetlands in most tropical regions such as Indonesia [14] and Vietnam [19], lack of comparing C stocks among different coastal wetlands, and lack of variations of total organic C (TOC) content with soil depth. Thus, the literature review shows that there are considerable sources of uncertainty in the past studies which need to be a comprehensive work to measure whole-ecosystem $\mathrm{C}$ stocks of different coastal wetlands on Hainan Island and to improve the comparison of different coastal wetlands and soil layers. Our objectives were to determine and compare $\mathrm{C}$ stocks of different coastal wetland types to determine $\mathrm{C}$ storage capacities of different soil layers. We hypothesized that:

1) Coastal wetlands in Hainan Island are a significant $C$ stock.

2) The highest $\mathrm{C}$ stocks of different coastal wetlands are found in mangrove ecosystems.

3) Most C within each coastal wetland is stored in the soil.

4) TOC content decreased with soil depth.

\section{Materials and Methods}

\author{
Study Area
}

Hainan Island $\left(19^{\circ} 20^{\prime}\right.$ to $20^{\circ} 10^{\prime} \mathrm{N}$; $108^{\circ} 21^{\prime}$ to $\left.111^{\circ} 03^{\prime} \mathrm{E}\right)$ is located off southern China. It has an area of 35,000 $\mathrm{km}^{2}$ and $1,823 \mathrm{~km}$ of coastline. Hainan Island's wetlands cover 242,000 ha, of which 164,000 are considered natural. Mangrove and seagrass are the major vegetation of coastal wetlands. The species of mangrove communities in Hainan Island are Sonneratia alba, Sonneratia caseolaris, Rhizophora apiculata, Kandelia candel, Aegiceras corniculatum, Avicennia marina, Bruguiera gymnorrhiza, Lumnitzera racemose, and Rhizophora stylosa [20]. Enhals acoroides, Halophila ovalis, and Halodule uninervis are the main species of seagrass on Hainan Island [21]. Additionally, other herbaceous vegetation like Acrostichum aureum, Paspalumcommersonii, and Schizachyrium sanguineum cover extensive coastal areas.

The island has a tropical marine climate. The mean annual temperature of the region is $24^{\circ} \mathrm{C}$, with a mean annual minimum and maximum of $18^{\circ} \mathrm{C}$ and $27^{\circ} \mathrm{C}$, respectively. The mean annual precipitation is $1,600 \mathrm{~mm}$ and the rainy season is from February to October. Hainan Island receives frequent tropical storms and typhoons.

\section{Field Sampling}

During July and August 2015 we sampled 93 different Hainan coastal wetland sites representing six types of coastal wetland. Within each site, whole-ecosystem C stocks were measured using the methodologies outlined by Kauffman and Donato [22].

\section{Vegetation Biomass Carbon Stocks}

Following the field investigation, we chose to ignore the vegetation in estuarine, muddy beach, and saltwater lake areas as these areas have no vegetation. We focused on the investigation of vegetation biomass in mangrove, delta, and seagrass bed ecosystems.

There were 93 sites in which both vegetation and soil were sampled (Fig. 1). Mangrove sampling sites were located at Dongzhai Harbor in Haikou, Qinglan Harbor in Wenchang, Tielu Harbor in Sanya, Danzhou City, and in Lingao County. We established sampling sites in forest areas with representative local vegetation and dominant plant communities. Tree communities were sampled in $10 \times 10 \mathrm{~m}$ quadrants, from which 15 samples were taken, with three replicates of each. For all mangrove plants in the quadrants, plant height $(\mathrm{H})$, diameter at breast height (DBH), and crown breadth were measured. Tree species, tree numbers and canopy density were recorded. C stocks of herbaceous understories were estimated from two $1 \times 1$ m quadrants within each sampling site.

The seagrass sampling sites were located in the Meilan district in Haikou, Li'an, and Xincun Harbor in Lingshui County, and in Haitou village in Wenchang city. 


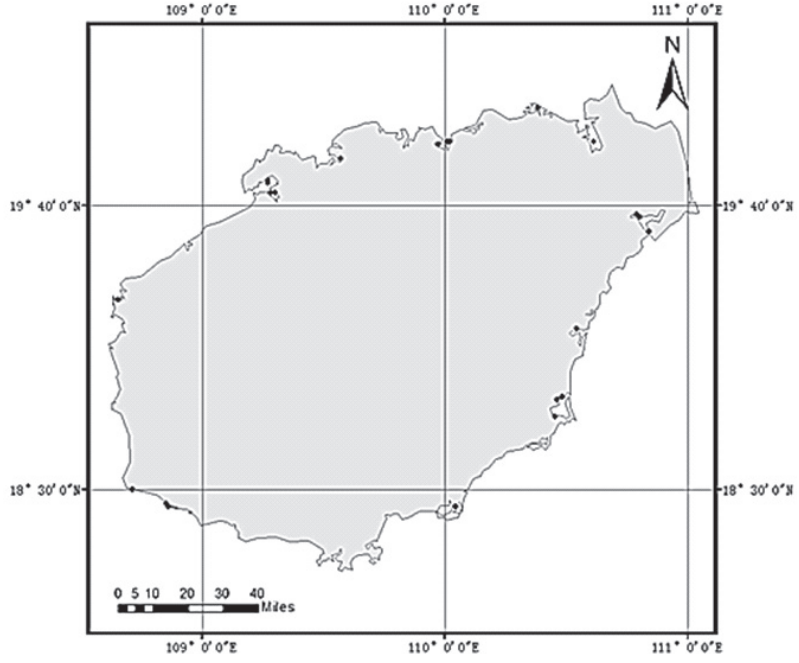

Fig. 1. Sampling locations of coastal wetland ecosystems on Hainan Island.

We adopted the whole-plant collection method. We used 10 sampling points consisting of $1 \times 1 \mathrm{~m}$ quadrants at each sampling site. To estimate the mean density of the seagrass, we placed a $1 \times 1 \mathrm{~m}$ square plastic frame randomly into the quadrant and removed all the seagrass within the frame.
Soil, including silt and sand attached to the seagrass, was washed off. Samples were then dried under shade in a ventilated place and weighed. As seagrass is immersed in water, there were some losses during digging, which we estimated as $5 \%$ by mass. The seagrass was divided into two types. The first was a mixture of Halophila ovalis and Halodule uninervis. These two species are relatively sparse; thus they were classified as 'other seagrass.' The second was Enhals acoroides, which we collected at Lian and Xincun harbors.

The field sampling sites for the delta ecosystem were located at the Wanglou Harbor in Ledong County. Again, we again used the whole-plant collection method. Delta ecosystems with modest canopy and vegetation densities were selected. We used a $1 \times 1 \mathrm{~m}$ square plastic frame to establish sampling locations, and dug up all the grass within them. The excavation depth was at least $60 \mathrm{~cm}$ to ensure that all underground roots were collected. We placed all excavated vegetation on voile fabric and cleaned it. The vegetation was then dried, weighed, and enclosed in the fabric.

\section{Soil Carbon Storage}

From June to July 2015 we investigated the soil C storage in each ecosystem. As sampling was based on

Table 1. Allometric equations for calculating aboveground and root biomass (in $\mathrm{kg}$ ) of mangroves, based on diameter at breast height $(\mathrm{DBH}, \mathrm{cm})$ and specific gravity $\left(\mathrm{g} \mathrm{cm}^{-3}\right)$.

\begin{tabular}{|c|c|c|}
\hline Species & Allometric equation & References \\
\hline \multicolumn{3}{|c|}{ Allometric equations for aboveground biomass } \\
\hline S. alba & $\mathrm{W}_{\text {Top }}=0.251 \rho \mathrm{DBH}^{2.46}\left(\rho=0.475, \mathrm{R}^{2}=0.99, n=15\right)$ & [23] \\
\hline S. caseolaris & $\mathrm{W}_{\text {Top }}=0.251 \rho \mathrm{DBH}^{2.46}\left(\rho=0.340, \mathrm{R}^{2}=0.99, n=15\right)$ & [23] \\
\hline R. apiculata & $\lg \mathrm{gW}_{\text {Top }}=2.3181 \mathrm{gH}_{1.3}-1.671\left(\mathrm{R}^{2}=0.98, n=73\right)$ & [24] \\
\hline K. candel & $\mathrm{W}_{\text {Top }}=0.0341\left(\mathrm{DBH}^{2} \mathrm{H}\right)^{1.03}\left(\mathrm{R}^{2}=0.98, n=25\right)$ & [25] \\
\hline A. corniculatum & $\log _{\text {Top }}=1.496+0.465 \log \left(\mathrm{DBH}^{2} * \mathrm{H}\right)\left(\mathrm{R}^{2}=0.94, n=15\right)$ & [26] \\
\hline A. marina & $\log _{\text {Top }}=2.092+0.529 \log \left(\mathrm{DBH}^{2} * \mathrm{H}\right)\left(\mathrm{R}^{2}=0.45, n=17\right)$ & [26] \\
\hline B. gymnorrhiza & $\mathrm{W}_{\text {Top }}=0.186 \mathrm{DBH}^{2.31}\left(\mathrm{R}^{2}=0.99, n=17\right)$ & [27] \\
\hline L. racemosa & $\mathrm{W}_{\text {Top }}=0.102 \mathrm{DBH}^{2.50}\left(\mathrm{R}_{2}=0.97, n=70\right)$ & [28] \\
\hline R. stylosa & $\mathrm{W}_{\text {Tор }}=2.465 \lg (\mathrm{DBH})-0.696\left(\mathrm{R}^{2}=0.99, n=6\right)$ & [29] \\
\hline \multicolumn{3}{|c|}{ Allometric equations for root biomass } \\
\hline S. alba & $\mathrm{W}_{\mathrm{R}}=0.199^{0.899} \mathrm{DBH}^{2.22}\left(\rho=0.475, \mathrm{R}^{2}=0.99, n=26\right)$ & [23] \\
\hline S. caseolaris & $\mathrm{W}_{\mathrm{R}}=0.199^{0.899} \mathrm{DBH}^{2.22}\left(\rho=0.475, \mathrm{R}^{2}=0.99, n=26\right)$ & [23] \\
\hline R. apiculata & $\operatorname{lgW}_{\mathrm{R}}=1.5221 \mathrm{gDBH}_{1.3}-1.707\left(\mathrm{R}^{2}=0.84, n=18\right)$ & [24] \\
\hline K. candel & $\mathrm{W}_{\mathrm{R}}=0.745\left(\mathrm{~W}_{\mathrm{Top}}\right)^{0.810}\left(\mathrm{R}^{2}=0.97, n=5\right)$ & [25] \\
\hline A. corniculatum & $\log _{\mathrm{R}}=0.967+0.303 \log \left(\mathrm{DBH}^{2} * \mathrm{H}\right)\left(\mathrm{R}^{2}=0.93, n=20\right)$ & [26] \\
\hline A. marina & $\log _{\mathrm{R}}=1.361+0.615 \log \left(\mathrm{DBH}^{2} * \mathrm{H}\right)\left(\mathrm{R}^{2}=0.92, n=27\right)$ & [26] \\
\hline B. gymnorrhiza & $\operatorname{lgW_{\mathrm {R}}}=1.5541 \mathrm{~g}\left(\mathrm{DBH}^{2} \mathrm{H}\right)-0.328\left(\mathrm{R}_{2}=0.99, n=17\right)$ & [27] \\
\hline R. stylosa & $\mathrm{W}_{\mathrm{R}}=1.8601 \mathrm{~g}(\mathrm{DBH})-0.583\left(\mathrm{R}^{2}=0.92, n=5\right)$ & [29] \\
\hline
\end{tabular}


the area of each ecosystem, we sampled 14 quadrants in estuaries: nine at muddy beaches, 15 in mangroves, 12 from coastal saltwater lakes, 10 from seagrass beds, and four from deltas. A soil sample of $1.2 \mathrm{~m}$ in height and $50 \mathrm{~mm}$ inner diameter was used to take the samples. We collected soil three times randomly in each quadrant for replication and obtained 192 soil profiles. The soil was systematically divided into depth intervals of $0-20$, 20-40, 40-60, 60-80, and 80-100 cm.

\section{Sample Preparation and Analysis}

All seagrass and vegetation of delta ecosystem samples were dried at $60^{\circ} \mathrm{C}$ until their weights were constant. Soil samples that measured bulk density were dried at $65^{\circ} \mathrm{C}$ and weighed. Soil samples for measuring physicochemical characteristics were dried under ventilation in the absence of light, then grated and sifted to assess soil grain diameters and organic carbon content. The specific gravities of tree wood samples were estimated by the ratio of the oven-dried weights and their volumes. The organic carbon content was obtained via loss on ignition measurement. Two grams of the pulverized sediments were first dried at $60^{\circ} \mathrm{C}$ in a drying oven for $2 \mathrm{~h}$, and then heated at $550^{\circ} \mathrm{C}$ in a temperature-monitored muffle furnace for $5 \mathrm{~h}$. We subtracted the weight from before and after combustion at $550^{\circ} \mathrm{C}$ to calculate organic carbon content.

\section{Ecosystem C Storage Estimation Procedure}

Vegetation $\mathrm{C}$ stocks were estimated from mangrove trees, seagrass, and delta vegetation. Mangrove biomass was calculated using allometric equations (Table 1). The tree biomasses of the species S.alba and S.caseolaris were estimated using common allometric equations [23], whereas the biomasses of other species were calculated using specific equations. The method of calculating the $\mathrm{C}$ stock of the trees was to multiply the tree biomass by the wood $\mathrm{C}$ content. Likewise, the mangrove root biomasses of the species S.alba and S.caseolaris were estimated using the common allometric equations [23], and the remaining equations were calculated using specific equations (Table 1). The root $\mathrm{C}$ stock was calculated by multiplying the root mass by $\mathrm{C}$ content. The $\mathrm{C}$ content of the mangrove was 0.48 aboveground and 0.39 for the root biomass [22]. The $\mathrm{C}$ content of the aboveground mass of the herbaceous vegetation was calculated using a factor of 0.45 of the total [22].

The seagrass and delta vegetation biomasses were estimated according to Eq. (1):

$$
\mathrm{B}_{\mathrm{i}}=\mathrm{d}_{\mathrm{i}} \times \mathrm{S}_{\mathrm{i}}
$$

...where $\mathrm{B}_{\mathrm{i}}=$ biomass of species $\mathrm{i}(\mathrm{Mg}), \mathrm{d}_{\mathrm{i}}=$ biomass of species i per unit area $\left(\mathrm{Mg} \mathrm{ha}^{-1}\right)$, and $\mathrm{S}_{\mathrm{i}}=$ area covered by species I (ha).

The soil C stocks were estimated up to $1 \mathrm{~m}$ in depth. There was a high $\mathrm{C}$ concentration throughout the top meter of the soil profile, with a decrease below $1 \mathrm{~m}$ [14], and experimental conditions were limited. Thus, the soil layers were divided into five depth intervals of 0-20, 20$40,40-60,60-80$, and $80-100 \mathrm{~cm}$. The soil C stock was calculated according to Eq. (2):

$$
\begin{gathered}
\text { Soil C stocks }\left(\mathrm{MgC} \mathrm{ha}^{-1}\right)=\text { bulk soil density } \\
\left(\mathrm{g} \mathrm{cm}^{-3}\right) \times \operatorname{TOC}(\%) \times \text { depth interval }(\mathrm{cm})
\end{gathered}
$$

The ecosystem $\mathrm{C}$ stock is comprised of vegetation and soil $\mathrm{C}$ stocks. The total $\mathrm{C}$ stocks of coastal wetland ecosystems on Hainan Island was calculated by multiplying the mean value for each ecosystem by its area, and then summing them.

\section{Statistical Analysis}

We adopted a one-factor ANOVA followed by a Duncan post-hoc test to test for differences in TOC content and $\mathrm{C}$ stocks of each ecosystem, and to assess whether these values decreased with soil depth. The data was examined for homogeneity of variance using Levene's test prior to statistical analysis. For all statistical tests, the significance level was accepted at $P \leq 0.05$. SPSS 19.0 was used to process the data.

\section{Results and Disscussion}

\section{Stock Estimates of the Seagrass Bed Ecosystems}

The biomass of Enhals acoroides was far higher than 'other seagrass' (Table 2). The area of the seagrass beds on Hainan Island was 502.55 ha, and the total seagrass biomass was 1,092.69 Mg. Common allometric equations were used to calculate the seagrass bed vegetation $\mathrm{C}$ stocks [23]. We estimated that $\mathrm{C}$ stocks of the seagrass bed ecosystem were $10.58 \pm 0.43 \mathrm{MgC} \cdot \mathrm{ha}^{-1}$. The results proved that biomass of different seagrass species was distinct as species differed in size [30]. C stocks of the seagrass beds on Hainan Island were considerably lower

Table 2. Characteristics of the seagrass ecosystem in Hainan Island.

\begin{tabular}{|c|c|c|c|c|c|}
\hline Type & Height $(\mathrm{cm})$ & Coverage (\%) & Soil texture & $\begin{array}{c}\text { Dry biomass by } \\
\text { area }\left(\mathrm{Mg} \mathrm{ha}^{-1}\right)\end{array}$ & $\begin{array}{c}\text { Total vegetation C stock } \pm \text { SE } \\
\left.(\mathrm{MgC} \mathrm{ha})^{-1}\right)\end{array}$ \\
\cline { 1 - 4 } Other seagrass & $0.8-1.5$ & $40-100$ & Sand & $0.18-0.76$ & \multirow{2}{*}{$10.48 \pm 0.43$} \\
\cline { 1 - 4 } Enhalus acodoides & $50.2-71.7$ & $40-89$ & Sand & $8.34-13.70$ & \multirow{2}{*}{} \\
\hline
\end{tabular}


Table 3. Community, tree density, above-ground biomass, root biomass, vegetation biomass, and total vegetation $\mathrm{C}$ stocks $(\mathrm{mean} \pm \mathrm{SE})$ of mangrove forests on Hainan Island, China.

\begin{tabular}{|c|c|c|c|c|c|}
\hline Community & $\begin{array}{c}\text { Tree density } \\
\left(\mathrm{ha}^{-1}\right)\end{array}$ & $\begin{array}{c}\text { Aboveground } \\
\text { biomass }\left(\mathrm{MgC} \mathrm{ha}{ }^{-1}\right)\end{array}$ & $\begin{array}{c}\text { Root biomass } \\
\left(\mathrm{MgC} \mathrm{ha}^{-1}\right)\end{array}$ & $\begin{array}{c}\text { Vegetation biomass } \\
\left(\mathrm{Mg} \mathrm{C} \mathrm{ha}^{-1}\right)\end{array}$ & $\begin{array}{c}\text { Total vegetation C } \\
\text { stock }(\mathrm{MgC} \mathrm{ha}\end{array}$ \\
\hline L. racemosa & 3,000 & 28.74 & 10.37 & 39.11 & $17.33 \pm 0.81$ \\
\hline S. alba & 2,200 & 34.25 & 17.90 & 52.15 & $23.11 \pm 1.53$ \\
\hline $\begin{array}{c}\text { L. racemosa }+ \text { B.sexangula }+ \\
\text { X.koenig }\end{array}$ & 5,867 & 149.22 & 112.22 & 261.43 & $115.87 \pm 13.41$ \\
\hline E.agallocha+B. sexangula & 1,233 & 34.66 & 21.89 & 56.55 & $25.07 \pm 1.27$ \\
\hline H. littoralis & 1,000 & 155.92 & 76.90 & 232.82 & $103.19 \pm 8.34$ \\
\hline R. Apiculata & 233 & 33.29 & 16.31 & 49.60 & $21.98 \pm 2.75$ \\
\hline R. stylosa & 4,700 & 249.87 & 99 & 348.86 & $154.61 \pm 16.23$ \\
\hline A. marina & 7,466 & 86.93 & 49.07 & 136.00 & $60.27 \pm 10.42$ \\
\hline B.sexangula+ B.gymnorrhiza & 2,966 & 308.77 & 112.70 & 421.47 & $186.80 \pm 29.48$ \\
\hline S. caseolaris & 1,367 & 196.13 & 80.49 & 276.62 & $122.60 \pm 19.27$ \\
\hline K. candel & 2,333 & 60.56 & 32.97 & 93.52 & $41.45 \pm 8.42$ \\
\hline $\begin{array}{c}\text { B.sexangula }+ \\
\text { B.sexangulavarrhynchopetala }\end{array}$ & 1,833 & 203.66 & 87.38 & 291.05 & $128.99 \pm 18.47$ \\
\hline Mean & - & 109.00 & 50.25 & 159.25 & $70.58 \pm 11.68$ \\
\hline
\end{tabular}

than the global average of $83 \mathrm{MgC} \mathrm{ha}^{-1}$ [31]. It was evident that the vegetation structure of seagrass on Hainan Island was simple with a single composition. Only three species of seagrass grew independently. Therefore, the biomass and productivity of vegetation on Hainan Island is lower than the global average [32]. Mean seagrass $\mathrm{C}$ stocks were $25.7 \mathrm{MgC} \mathrm{ha}^{-1}$ in the Gulf of Mexico [33]. Compared with seagrass in Hainan Island, the height was mostly over $50 \mathrm{~cm}$.

\section{Stock Estimates of Mangrove Ecosystems}

We identified 12 species in Hainan Island. A combination of B.sexangula and B.gymnorrhiza possessed the highest $\mathrm{C}$ stock, followed by a combination of E.agallocha and B.sexangula (Table 3). The mean vegetation $\mathrm{C}$ stocks of the mangrove forest in Hainan Island were $70.58 \mathrm{MgC} \mathrm{ha}^{-1}$ (Table 3). The result is similar to that reported for Yingluo Bay [34]. The study demonstrated that there were significant differences in C stocks among mangrove types, which was opposite to those along the Pacific and Caribbean coasts of Honduras [35]. For different plant structures, root biomass occupied $26.5 \sim 42.9 \%$ vegetation $\mathrm{C}$ stocks. Roots played an essential role in $\mathrm{C}$ stocks as decomposition of roots deeply influenced carbon sequestration [36]. The vegetation $\mathrm{C}$ stock of mangroves on Hainan Island was similar to that of mangroves in the Sundarbans [37] and Yingluo Bay [34], and substantially lower than that in Borneo and Sulawesi [14] and Palau, Micronesia [15]. Based on the height and DBH of the mangrove trees on Hainan Island, they are medium-sized forests compared to most others in the tropical zone.

\section{Stock Estimates of Delta Ecosystem Vegetation}

Mean biomass of the delta ecosystem was 15.71 $\mathrm{MgC} \mathrm{ha}{ }^{-1}$. We calculated that vegetation $\mathrm{C}$ stocks of the delta ecosystem were $6.99 \pm 0.59 \mathrm{MgC} \mathrm{ha}^{-1}$ (Table 4). The delta ecosystem was divided into different types and had large-scale distribution. The vegetation $\mathrm{C}$ stocks of delta ecosystems on Hainan Island were three-fold lower than that of the Pearl River Delta [38]. We investigated the fact that the soil of deltas on Hainan Island was sandy, whereas those elsewhere are predominantly loam and clay soils [39], suggesting that the soil texture had a significant influence on vegetation carbon storage. The study of carbon pool in an area of

Table 4. Height, coverage, soil texture, range of biomass density, mean of biomass density, and vegetation C stocks (mean $\pm \mathrm{SE})$ of delta ecosystem on Hainan Island, China.

\begin{tabular}{|c|c|c|c|c|c|}
\hline Height $(\mathrm{cm})$ & Coverage (\%) & Soil texture & $\begin{array}{c}\text { Range of biomass density } \\
\left(\mathrm{MgC} \mathrm{ha}^{-1}\right)\end{array}$ & $\begin{array}{c}\text { Mean biomass density } \\
\left(\mathrm{MgC} \mathrm{ha}^{-1}\right)\end{array}$ & $\begin{array}{c}\text { Vegetation C stock } \\
\left(\mathrm{MgC} \mathrm{ha}^{-1}\right)\end{array}$ \\
\hline $0.8-1.5$ & $40-100$ & sand & $7.16-24.22$ & 15.71 & $6.99 \pm 0.59$ \\
\hline
\end{tabular}


Table 5. Depth, bulk density, TOC, and soil C stocks of coastal wetland ecosystems. Values given as mean $\pm \mathrm{SE}$.

\begin{tabular}{|c|c|c|c|}
\hline $\begin{array}{l}\text { Depth } \\
(\mathrm{cm})\end{array}$ & $\begin{array}{l}\text { Bulk density } \\
\left(\mathrm{g} \mathrm{cm}^{-3}\right)\end{array}$ & TOC (\%) & $\begin{array}{l}\text { Soil C stock } \\
\left(\mathrm{MgC} \mathrm{ha}^{-1}\right)\end{array}$ \\
\hline \multicolumn{4}{|c|}{ Estuaries } \\
\hline $0-20$ & $1.17 \pm 0.25$ & $2.14 \pm 0.37 \mathrm{ABa}$ & $50.08 \pm 7.32 \mathrm{BCa}$ \\
\hline $20-40$ & $1.29 \pm 0.28$ & $1.83 \pm 0.32 \mathrm{Ba}$ & $47.21 \pm 9.44 \mathrm{Aab}$ \\
\hline $40-60$ & $1.31 \pm 0.22$ & $1.53 \pm 0.45 \mathrm{Bab}$ & $40.09 \pm 10.37 \mathrm{Bb}$ \\
\hline $60-80$ & $1.37 \pm 0.34$ & $1.42 \pm 0.39 \mathrm{ABb}$ & $38.91 \pm 7.32 \mathrm{Cb}$ \\
\hline $80-100$ & $1.40 \pm 0.22$ & $1.23 \pm 0.25 \mathrm{Bb}$ & $34.44 \pm 7.32 \mathrm{Bb}$ \\
\hline Total & & & $210.73 \pm 19.38$ \\
\hline \multicolumn{4}{|c|}{ Muddy beaches } \\
\hline $0-20$ & $1.22 \pm 0.21$ & $2.24 \pm 0.98 \mathrm{ABa}$ & $54.66 \pm 5.28 \mathrm{Ba}$ \\
\hline $20-40$ & $1.25 \pm 0.12$ & $2.02 \pm 1.21 \mathrm{Ba}$ & $50.50 \pm 6.41 \mathrm{Aa}$ \\
\hline $40-60$ & $1.29 \pm 0.15$ & $1.83 \pm 0.77 \mathrm{ABb}$ & $47.21 \pm 5.72 \mathrm{Bb}$ \\
\hline $60-80$ & $1.36 \pm 0.18$ & $1.70 \pm 0.98 \mathrm{ABb}$ & $46.24 \pm 9.25 \mathrm{Bb}$ \\
\hline $80-100$ & $1.37 \pm 0.34$ & $1.62 \pm 0.74 \mathrm{Ab}$ & $44.39 \pm 8.26 \mathrm{Ab}$ \\
\hline Total & & & $243.00 \pm 14.21$ \\
\hline \multicolumn{4}{|c|}{ Coastal saltwater lakes } \\
\hline $0-20$ & $1.29 \pm 0.27$ & $1.36 \pm 0.49 \mathrm{Ba}$ & $35.10 \pm 3.72 \mathrm{Ca}$ \\
\hline $20-40$ & $1.38 \pm 0.44$ & $1.30 \pm 0.48 \mathrm{Ca}$ & $35.88 \pm 6.34 \mathrm{Ba}$ \\
\hline $40-60$ & $1.43 \pm 0.20$ & $1.12 \pm 0.24 \mathrm{Ba}$ & $32.03 \pm 8.12 \mathrm{Bb}$ \\
\hline $60-80$ & $1.49 \pm 0.27$ & $1.10 \pm 0.14 \mathrm{Ba}$ & $32.78 \pm 9.25 \mathrm{Cb}$ \\
\hline $80-100$ & $1.52 \pm 0.23$ & $1.04 \pm 0.19 \mathrm{Ca}$ & $31.62 \pm 4.24 \mathrm{Bb}$ \\
\hline Total & & & $167.41 \pm 21.72$ \\
\hline \multicolumn{4}{|c|}{ Mangroves } \\
\hline $0-20$ & $1.21 \pm 0.26$ & $3.52 \pm 0.97 \mathrm{Aa}$ & $85.12 \pm 11.48 \mathrm{Aa}$ \\
\hline $20-40$ & $1.27 \pm 0.28$ & $3.18 \pm 0.46 \mathrm{Aa}$ & $80.77 \pm 7.38 \mathrm{Aa}$ \\
\hline $40-60$ & $1.32 \pm 0.30$ & $2.72 \pm 0.85 \mathrm{Aa}$ & $71.81 \pm 9.31 \mathrm{Aa}$ \\
\hline $60-80$ & $1.37 \pm 0.21$ & $2.34 \pm 0.98 \mathrm{Ab}$ & $64.12 \pm 4.26 \mathrm{Aa}$ \\
\hline $80-100$ & $1.41 \pm 0.31$ & $1.85 \pm 0.73 \mathrm{Ab}$ & $52.17 \pm 7.83 \mathrm{Aab}$ \\
\hline Total & & & $353.99 \pm 30.92$ \\
\hline \multicolumn{4}{|c|}{ Deltas } \\
\hline $0-20$ & $1.20 \pm 0.06$ & $1.69 \pm 0.47 \mathrm{Ba}$ & $40.56 \pm 9.43 \mathrm{Ca}$ \\
\hline $20-40$ & $1.37 \pm 0.17$ & $1.56 \pm 0.28 \mathrm{Bb}$ & $42.74 \pm 6.83 \mathrm{Aa}$ \\
\hline $40-60$ & $1.41 \pm 0.03$ & $1.12 \pm 0.22 \mathrm{Bbc}$ & $31.58 \pm 4.37 \mathrm{Bb}$ \\
\hline $60-80$ & $1.46 \pm 0.09$ & $1.09 \pm 0.18 \mathrm{Bc}$ & $31.83 \pm 8.24 \mathrm{Cb}$ \\
\hline $80-100$ & $1.49 \pm 0.12$ & $1.08 \pm 0.13 \mathrm{Bc}$ & $32.18 \pm 7.42 \mathrm{Bb}$ \\
\hline Total & & & $178.89 \pm 10.35$ \\
\hline \multicolumn{4}{|c|}{ Seagrass beds } \\
\hline $0-20$ & $1.37 \pm 0.20$ & $2.32 \pm 0.57 \mathrm{Aa}$ & $63.57 \pm 8.47 \mathrm{Aa}$ \\
\hline $20-40$ & $1.47 \pm 0.24$ & $2.11 \pm 0.37 \mathrm{Aa}$ & $62.03 \pm 4.51 \mathrm{Aa}$ \\
\hline
\end{tabular}

Table 5. Contimued.

\begin{tabular}{|c|c|c|c|}
\hline $40-60$ & $1.47 \pm 0.22$ & $1.82 \pm 0.25 \mathrm{ABa}$ & $53.51 \pm 8.25 \mathrm{Aa}$ \\
\hline $60-80$ & $1.55 \pm 0.09$ & $1.81 \pm 0.11 \mathrm{Aab}$ & $56.11 \pm 9.36 \mathrm{Aa}$ \\
\hline $80-100$ & $1.59 \pm 0.12$ & $1.64 \pm 0.42 \mathrm{Ab}$ & $52.15 \pm 6.99 \mathrm{Aa}$ \\
\hline Total & & & $287.37 \pm 20.62$ \\
\hline
\end{tabular}

Note: Different capital letters indicate significant differences in TOCs and C stocks of different coastal wetland ecosystems, and different lower case letters indicate significant differences in TOCs and C stocks of different soil layers.

north Nile Delta, Egypt also proved that sand was the most negative factor correlating to $\mathrm{C}$ pools [40]. Soil C Stock Estimates

The overall mean TOC for estuaries, muddy beaches, coastal saltwater lakes, mangroves, deltas, and seagrass bed ecosystems were $1.63,1.88,1.18,2.72,1.31$, and $1.94 \%$, respectively. The TOC of the mangroves was far higher than other ecosystems. The TOCs of seagrass and muddy beach ecosystems were relatively high. TOC tended to decrease with soil depth (Fig. 2), such that the highest TOC was in the $0-20 \mathrm{~cm}$ layer, except in coastal saltwater lakes and deltas, where it was in the $20-40 \mathrm{~cm}$ soil layer. The study revealed that topsoil was the key point of soil sequestration [41]. The TOC contents of Hainan Island were similar to those of some medium-sized forests in the Asia-Pacific region [14] and higher than those of common forests in southern China [46]. The results of comparison further explained that Hainan mangroves corresponded to medium-sized forests of the Asia-Pacific region [14] and the Mexican Caribbean [17]. The TOC content of seagrass bed ecosystems on Hainan was four-fold lower than that reported for Australia [45]. Different soil textures and plant sizes between two locations led to the different soil C stocks. But seagrass in Hainan Island near fish farming increased the TOC as nutrient enrichment could enhance plant-derived contributions to the TOC [43]. The TOC content of the estuaries on Hainan Island was consistent with the values for the Mississippi and Atchafalaya rivers [44] and the Gironde, Loire, and Seine estuaries [45] - which are all located in temperate zones. Strong seasonality influenced the TOC in the estuaries [46]. Therefore, seasonality resulted in a certain error in the calculation result.

In the different soil layers soil bulk density increased with the increase of depth, while TOC content decreased. Raised soil compaction and water content resulted in the increase of soil bulk. The result was essentially consistent with that reported for mangrove ecosystems in the Indo-Pacific region [14]. There was a significant decline in soil $\mathrm{C}$ stocks with the increase of soil depth. The difference in soil C stocks of estuaries, muddy beaches, coastal saltwater lakes, mangroves, deltas, and seagrass bed ecosystems between the top layer and the deepest layer was 15.64, 10.27, 4.26, 32.95, 10.56 , and $11.42 \mathrm{MgC} \mathrm{ha}^{-1}$. Furthermore, our results are in 
agreement in that the carbon balance is closely related to the water content at different soil depths [47].

ANOVA $\left(\mathrm{F}_{2,24}=40.26, \rho<0.05\right)$ showed that different soil layers had significant differences in TOC. Soil depth had a substantial influence on TOC content. An ANOVA $(\mathrm{F} 1,105=6.80, \rho<0.05)$ of TOCs from different coastal wetland ecosystems indicated that the ecosystems had quite different TOCs and C stocks (Table 5).

The total soil $\mathrm{C}$ stocks of estuaries, muddy beaches, coastal saltwater lakes, mangroves, deltas, and seagrass bed ecosystems were 210.73, 243, 167.41, 353.99, 178.89, and $287.37 \mathrm{MgC} \mathrm{ha}^{-1}$. Soil C stocks of mangroves were the richest and much higher than other ecosystems. Soil C stocks of estuaries, muddy beaches, and seagrass bed ecosystems were the second richest, while those of coastal saltwater lakes and deltas were the poorest. Soil C stocks were affected by soil texture and hydrological environment. Soil texture of coastal saltwater lakes and deltas was sand, which was difficult for storing C.

\section{Ecosystem C Storage of Coastal Wetland Ecosystems}

Combining the vegetation and soil $\mathrm{C}$ stock estimates allowed for the estimation of total $\mathrm{C}$ stored by coastal wetland ecosystems on Hainan Island. The $\mathrm{C}$ stock of estuaries, muddy beaches, coastal saltwater lakes, mangroves, deltas, and seagrass bed ecosystems were

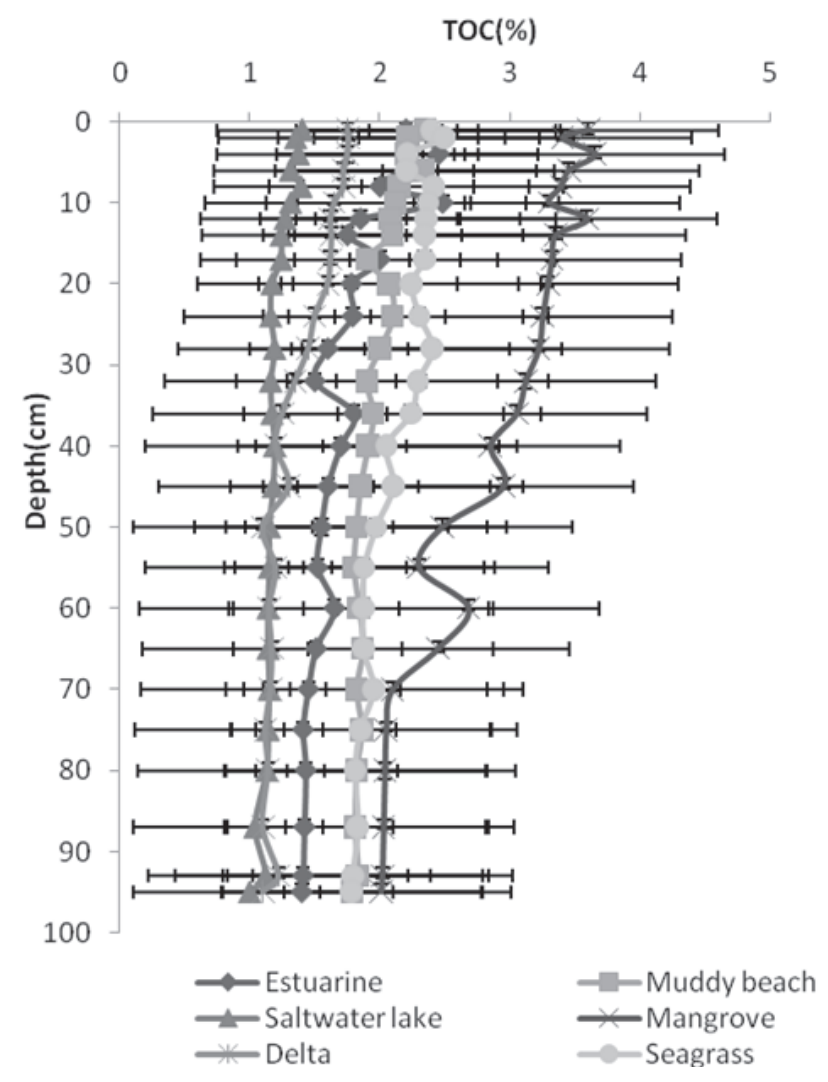

Fig. 2. Variations of organic C content (TOC, \%) by soil depth in various coastal wetland ecosystems.

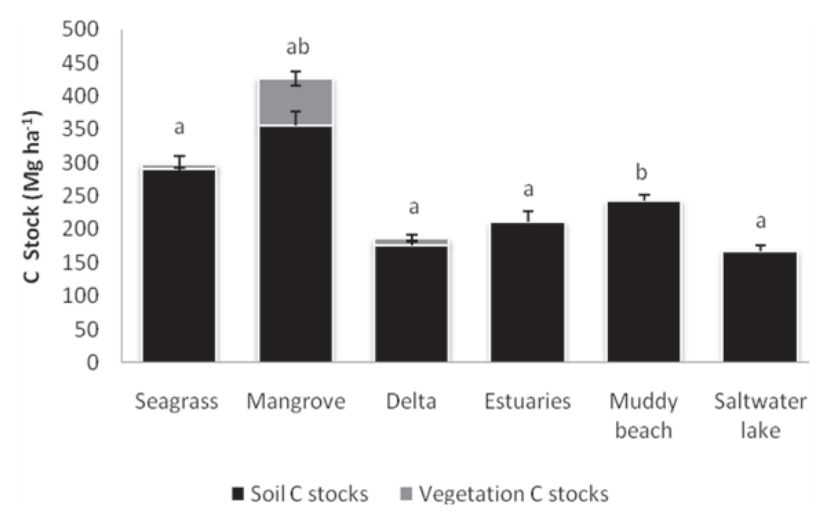

Fig. 3. Comparison of $\mathrm{C}$ stocks of different coastal wetland ecosystems on Hainan Island. $\mathrm{C}$ stocks include vegetation and soil stocks of up to one meter in depth. Vertical bars denote standard errors.

210.73, 243, 167.41, 426.57, 185.88, and 297.85 $\mathrm{MgC}$ $\mathrm{ha}^{-1}$, respectively. The results roughly applied to similar tropical and subtropical regions. We can calculate the $\mathrm{C}$ stocks of different coastal wetland ecosystems in tropical and subtropical regions that were based on the results of Hainan Island. For other regions with different climates, the results could be used to contrast and clarify the impact factor of $\mathrm{C}$ stocks for further study.

Soil C stocks dominated total C stocks, accounting for $83 \%, 96.24 \%$, and $96.48 \%$ of $\mathrm{C}$ stocks of mangroves, deltas, and seagrass bed ecosystems, respectively. This suggested that soil $\mathrm{C}$ stocks area occupied more predominant $\mathrm{C}$-stock reserves than vegetation $\mathrm{C}$ stocks. Land use change caused substantial releases of $\mathrm{C}$ when soil $\mathrm{C}$ sequestration ceases to function [48]. C stocks of the coastal wetland ecosystem on Hainan Island were 296.74 $\mathrm{MgC} \mathrm{ha}^{-1}$, which was higher than that of terrestrial forests [49].

However, there are some limitations in the calculation of $\mathrm{C}$ stocks. We only calculated the soil $\mathrm{C}$ stocks from the upper meter of the soil layer. Donato evaluated the C stock of at least three meters of soil [14]. Thus, our estimates could underestimate ecosystem $\mathrm{C}$ stocks.

According to the size of each coastal wetland ecosystem, we calculated that estuaries, muddy beaches, coastal saltwater lakes, mangroves, deltas, and seagrass bed ecosystems stored up to $14.05 \times 10^{5}, 2.18 \times 10^{5}, 12.29 \times 10^{5}$, $27.06 \times 10^{5}, 0.04 \times 10^{5}$, and $0.81 \times 10^{5} \mathrm{Mg}$ of $\mathrm{C}$, respectively. These $\mathrm{C}$ stocks are vulnerable to decomposition and if degraded can be released to the atmosphere in the form of $\mathrm{CO}_{2}$ [50]. Total $\mathrm{C}$ stocks of coastal wetland ecosystems are equivalent to $1.83 \%$ of China's $\mathrm{CO}_{2}$ emissions in 2013 [51]. This means that if coastal wetland ecosystems were destroyed by land use change and climate effects, the $\mathrm{C}$ segregation of coastal wetland ecosystems on Hainan Island would release approximately $2 \%$ of the annual national emissions as $\mathrm{CO}_{2}$. The estimates of $\mathrm{C}$ storage of coastal wetland ecosystems are meaningful for preserving the ecological environment and controlling carbon emissions. 


\section{Conclusions}

The C stocks of estuaries, muddy beaches, coastal saltwater lakes, mangroves, deltas, and seagrass beds were 210.73, 243.00, 167.41, 426.57, 185.88, and 297.85 $\mathrm{MgC} \mathrm{ha}{ }^{-1}$, respectively. Mangroves were found to be the most carbon-rich ecosystem. The TOC of soil decreased with soil depth and was the highest in the top $0-20 \mathrm{~cm}$ layer. Topsoil was the key point of soil sequestration. Soil C stocks have more predominant $\mathrm{C}$-stock reserve than vegetation $\mathrm{C}$ stocks. The total $\mathrm{C}$ storage of coastal wetland ecosystems in Hainan Island was $56.51 \times 10^{5}$ $\mathrm{Mg}$ of $\mathrm{C}$, which is equivalent to approximately $2 \%$ of the annual national emissions as $\mathrm{CO}_{2}$.

\section{Acknowledgements}

This study was funded by National Natural Science Foundation (41676080), Special Fund for Forest Scientific Research in the Public Welfare (201504413) and Guangdong Province ForestryScience \& Technology Innovation Project (2017KJCX017, 2014KJCX021-02).

\section{References}

1. VALIPOUR M., SEFIDKOUHI M A G., RAEINI M. Selecting the best model to estimate potential evapotranspiration with respect to climate change and magnitudes of extreme events. Agricultural Water Management. 180, 50, 2017.

2. VALIPOUR M. Use of surface water supply index to assessing of water resources management in Colorado and Oregon, US. Advances in Agriculture, Sciences and Engineering Research. 3, 2, 631, 2013.

3. VALIPOUR M., MOUSAVI S M., VALIPOUR R., REZAEI E. A new approach for environmental crises and its solutions by computer modeling. The first international conference on environmental crises and its Solutions, Kish Island, Iran. 2013.

4. NELlEMANN C., CORCORAN E., DUARTE C M., VALDES L., DEYOUNG C. Blue Carbon: a rapid response assessment. United Nations Environment Programme. GRID-Arendal website. 2009.

5. MCLEOD E., CHMURA G.L., BOUILLON S., SALM R., BJÖRK M., DUARTE C.M., SILLIMAN B.R. A blueprint for blue carbon: toward an improved understanding of the role of vegetated coastal habitats in sequestering $\mathrm{CO}_{2}$. Frontiers in Ecology \& the Environment. 9, 10, 552, 2011.

6. ALEXANDER S., NELSON C.R., ARONSON J., LAMB D., CLIQUET A., ERWIN K.L., HOBBS R.J. Opportunities and challenges for ecological restoration within REDD+. Restoration Ecology. 19, 6, 683, 2011.

7. WANG D., WU R., LI Y. Characteristic coastal ecosystems of tropics in Hainan Island. Journal of tropical oceanography. 30, 26, 2011.

8. ZHANG X., LI P., LI P., XU X. Present conditions and prospects of study on coastal wetlands in China. Advances in Marine Science. 23, 87, 2005.

9. CORBERA E., SCHROEDERC H. Governing and implementing REDD+. Environmental Science \& Policy. 14, 89, 2011.
10. OLANDER L.P., GIBBS H.K., STEININGER M., SWENSON J.J., MURRAY B.C. Reference scenarios for deforestation and forest degradation in support of REDD: a review of data and methods. Environment Research Letters. 3, 2, 025011, 2008.

11. BERNAL B., MITSCH W J. A comparison of soil carbon pools and profiles in wetlands in Costa Rica and Ohio. Ecological Engineering. 34, 4, 311, 2008.

12. BRENNER J., JIMÉNEZ J.A., SARDÁ R., GAROLA A. An assessment of the non-market value of the ecosystem services provided by the Catalan coastal zone, Spain. Ocean\&Coastal Management. 53, 27, 2010.

13. BEAUMONT N.J., JONES L., GARBUTT A., HANSOM J.D., TOBERMAN M. The value of carbon sequestration and storage in coastal habitats. Estuarine, Coastal and Shelf Science. 137, 32, 2014.

14. DONATO D.K.J.B., KAUFFMAN J.B., MURDIYARSO D., KURNIANTO S., STIDHAM M., KANNINEN M. Mangroves among the most carbon-rich forests in the tropics. Nature Geoscience. 4, 5, 293, 2011.

15. KAUFFMAN J.B., HEIDER C., COLE T.G., DWIRE K.A., DONATO D.C. Ecosystem carbon stocks of Micronesian mangrove forests. Wetlands. 31, 2, 343, 2011.

16. PENDLETON L., DONATO D.C., MURRAY B.C., CROOKS S., JENKINS W A., SIFLEET S., MEGONIGAL P. Estimating global "blue carbon" emissions from conversion and degradation of vegetated coastal ecosystems. PloS one. 7, 9, e43542, 2012.

17. ADAME M F., KAUFFMAN J.B., MEDINA I., GAMBOA J.N., TORRES O., CAAMAL J.P., HERRERA-SILVEIRA J.A. Carbon stocks of tropical coastal wetlands within the karstic landscape of the Mexican Caribbean. PLoS One. 8, 2, e56569,2013

18. TU Z., CHEN X. Current status of coastal wetland resources in Hainan Island and strategies for protection. Wetland Science and Management. 10, 49, 2014.

19. TUE N T., DUNG L.V., NHUAN M.T., OMORI K. Carbon storage of a tropical mangrove forest in Mui $\mathrm{Ca} \mathrm{Mau}$ National Park, Vietnam. Catena. 121, 119, 2014.

20. ZHANG Q., SUI S. The mangrove wetland resources and their conservation in China. Journal of natural resources. 16, 1, 28, 2000.

21. WANG D.R., WU Z.J., CHEN C.H., LAN J .X., WU R., CHEN X .H., LI Y.C. Distribution of sea-grass resources and existing threat in Hainan Island. Marine environment science. 1, 8, 2012.

22. KAUFFMAN J.B., DONATO D. Protocols for the measurement, monitoring andreporting of structure, biomass and carbon stocks in mangrove forests. Center for International Forest Research, CIFOR Working Paper. 86. 2012.

23. KOMIYAMA A., POUNGPARN S., KATO S. Common allometric equations for estimatingthe tree weight of mangroves. Journal of Tropical Ecology. 21, 471, 2005.

24. ONG J.E., GONG W.K., WONG C.H. Allometry and partitioning of the mangrove, Rhizophora apiculata. Forest Ecology and Management. 188, 395, 2004.

25. HOQUE A.T.M.R., SHARMA S., HAGIHARA A. Above and belowground carbon acquisition of mangrove kandelia obovata trees in Manko wetland, Okinawa, Japan. International Journal of Environment. 1, 7, 2011.

26. TAM N.F.Y., WONG Y.S., LAN C.Y., CHEN G.Z. Community structure and standing crop biomass of a mangrove forest in Futian Nature Reserve, Shenzhen, China. Hydrobiologia. 295, 193, 1995

27. CLOUGH B.F., SCOTT K. Allometric relationships for 
estimating above-ground biomass in six mangrove species. Forest Ecology and Management. 27, 117, 1989.

28. FROMARD F., PUIG H., MOUGIN E., MARTY G., BETOULLE J.L., CADAMURO L. Structure, aboveground biomass and dynamics of mangrove ecosystems: new data from French Guiana. Oecologia. 115, 1, 1998.

29. COMLEY B.W.T., MCGUINNESS K.A. Above- and below-ground biomass, and allometry, of four common northern Australian mangroves. 53, 431, 2005.

30. BELSHE E.F., MATEO M.A., GILLIS L.G., ZIMMER M., TEICHBERG M. Muddy waters: unintentional consequences of blue carbon research obscure our understanding of organic carbon dynamics in seagrass ecosystems. Frontiers in Marine Science. 4, 125, 2017.

31. RAY R., GANGULY D., CHOWDHURY C., DEY M., DAS S., DUTTA M.K., JANA T.K. Carbon sequestration and annual increaseof carbon stock in a mangrove forest. Atmospheric Environment. 45, 28, 5016, 2011.

32. YANG K., GUAN D.S. Changes in forest biomass carbon stock in the Pearl River Delta between 1989 and 2003. Journal of Environmental Sciences. 20, 1439, 2005.

33. THORHAUG A., POULOS H.M., LÓPEZ-PORTILLO J., KU T.C., BERLYN G.P. Seagrass blue carbon dynamics in the Gulf of Mexico: Stocks, losses from anthropogenic disturbance, and gains through seagrass restoration. Science of The Total Environment. 605, 626, 2017.

34. ELBASIOUNY H., ABOWALY M., ABU-ALKHEIR A., GAD A. Spatial variation of soil carbon and nitrogen pools by using ordinary Kriging method in an area of north Nile Delta, Egypt. Catena. 113, 70, 2014.

35. ATWOOD T.B., CONNOLLY R.M., ALMAHASHEER H., CARNELL P.E., DUARTE C.M., LEWIS C.J.E., SERRANO O. Global patterns in mangrove soil carbon stocks and losses. Nature Climate Change. 7 (7) 523, 2017.

36. LAVERY P.S., MATEO M.Á., SERRANO O., ROZAIMI M. Variability in the carbon storage of seagrass habitats and its implications for global estimates of blue carbon ecosystem service. PLoS ONE. 8, 9, e73748, 2013.

37. LIU S., JIANG Z., ZHANG J., WU Y., LIAN Z., HUANG X. Effect of nutrient enrichment on the source and composition of sediment organic carbon in tropical seagrass beds in the South China Sea. Marine pollution bulletin. 110 (1), 274, 2016.

38. BIANCHI T.S., GALLER J.J., ALLISON M.A. Hydrodynamic sorting and transport of terrestrially derived organic carbon in sediments of the Mississippi and Atchafalaya Rivers. Estuarine, Coastal and Shelf Science. 73, 211, 2007.

39. ETCHEBER H., TAILLEZ A., ABRIL G., GARNIER J., SERVAIS P., MOATAR F., COMMARIEU M.V. Particulate organic carbon in the estuarine turbidity maxima of the Gironde, Loire and Seine estuaries: origin and lability. Hydrobiologia. 588, 1, 245, 2007.
40. KUWAE T., KANDA J., KUBO A., NAKAJIMA F., OGAWA H., SOHMA A., SUZUMURA M. Blue carbon in human-dominated estuarine and shallow coastal systems. Ambio. 45, 3, 290, 2016.

41. BHOMIA R.K., KAUFFMAN J.B., MCFADDEN T.N. Ecosystem carbon stocks of mangrove forests along the Pacific and Caribbean coasts of Honduras. Wetlands ecology and management. 24, 2, 187, 2016.

42. OUYANG X., LEE S.Y., CONNOLLY R.M. The role of root decomposition in global mangrove and saltmarsh carbon budgets. Earth-Science Reviews. 2017.

43. FOURQUREAN J.W., DUARTE C.M., KENNEDY H., MARBA N., HOLMER M., MATEO M.A., SERRANO O. Seagrass ecosystems as a globally significant carbon stock. Nature Geoscience. 5, 7, 505, 2012.

44. HUANG X., HUANG L., LI Y., XU Z., FONG C.W., HUANG D., LIU S. Main seagrass beds and threats to their habitats in the coastal sea of South China. Chinese Science Bulletin. 51, 136, 2006.

45. DAN T.H., BRIX H. Effects of soil type and water saturation on growth, nutrient and mineral content of the perennial forage shrub Sesbania sesban. Agroforestry Systems, 91 (1), 173, 2017.

46. WANG G., GUAN D., PEART M R., CHEN Y., PENG Y. Ecosystem carbon stocks of mangrove forest in Yingluo Bay, Guangdong Province of South China. Forest Ecology and Management. 310, 539, 2013.

47. MACK M.C., SCHUUR E.A., BRET-HARTE M.S., SHAVER G.R., CHAPIN F.S. Ecosystem carbon storage in arctic tundra reduced by long-term nutrient fertilization. Nature. 431, 7007, 440, 2004.

48. PUGH T.A.M., ARNETH A., OLIN S., AHLSTRÖM A., BAYER A.D., GOLDEWIJK K.K., SCHURGERS G. Simulated carbon emissions from land-use change are substantially enhanced by accounting for agricultural management. Environmental Research Letters. 10, 12, 124008, 2015.

49. THURNER M., BEER C., SANTORO M., CARVALHAIS N., WUTZLER T., SCHEPASCHENKO D., SCHMULLIUS C. Carbon stock and density of northern boreal and temperate forests. Global Ecology and Biogeography, 23 (3), 297, 2014.

50. LOVELOCK C.E., ATWOOD T., BALDOCK J., DUARTE C.M., HICKEY S., LAVERY P.S., STEVEN A. Assessing the risk of carbon dioxide emissions from blue carbon ecosystems. Frontiers in Ecology and the Environment. 2017.

51. LIU Z., GUAN D., WEI W., DAVIS S J., CIAIS P., BAI J., ANDRES R.J. Reduced carbon emission estimates from fossil fuel combustion and cement production in China. Nature. 524, 7565, 335, 2015. 